\title{
Towards A Model to Improve English Language Standards in Schools: Impact of Socio-Economic Factors of Stakeholders
}

\author{
Viruli A. De Silva ${ }^{1} \&$ Hemamali Palihakkara $^{2}$ \\ ${ }^{1 \& 2}$ AHEAD SL Cell, Saegis Campus (www.saegis.edu.lk), Nugegoda, Sri Lanka \\ Correspondence: Dr. Viruli A. De Silva, Consultant - AHEAD SL Cell, Saegis Campus, Nugegoda, Sri Lanka.
}

Received: October 26, 2020

doi: 10.5539/elt.v13n12p43
Accepted: November 16, $2020 \quad$ Online Published: November 20, 2020

URL: https://doi.org/10.5539/elt.v13n12p43

\begin{abstract}
There is a dire need to enhance the English language standards in schools of developing countries using English as a second or Foreign language, due to its importance in employability and high-earning ability in the job market. Enhancing English language standards in schools is vital to improving the English language competence of school leavers and undergraduates to achieve an English language quality level as a nation, to produce diversified graduates of global quality, to address the unemployability problem in developing countries. Sri Lanka, with a rich history of a colonial era, is no exception. Studies on the influence of Socio-Economic factors of stakeholders on improving the English language standards in schools had received poor attention from past researchers, especially in the Sri Lankan education context. Hence, the overall purpose of this study is to develop a theoretical model, to explore the impact of socio-economic factors of stakeholders on English Language Standards in Sri Lankan schools. The study reviewed reliable secondary data published in scholarly extant literature, government Policy Documents, Research Reports of reputed institutions, etc., relevant to the above primary relationship and key concepts of the study. Six main stakeholders in the socio-economic context of the school English Language education were identified: (i) Education Policy Makers, (ii) School Management, (iii) School Principals, (iv) English Language Teachers, (v) Students, and (vi) Parents. An integrated, seven-construct conceptual model, labeled 'ELS Model' (English Language Standard Model), was developed, to examine the impact of socio-economic factors of the six stakeholders on improving English Language Standards in schools. This ELS Model presents original insights and future directions to scholars/researchers and significant implications for policymakers.
\end{abstract}

Keywords: education policy maker, English teacher, developing countries, parent, principal, school management, student, Sri Lanka

\section{Introduction}

\subsection{Background of the Study}

Enhancing the English Language standards in schools of the developing countries has become of utmost importance over the years since globalization, witnessing its importance in the local and international job markets for the school leavers and graduates who are non-native English speakers. According to Roshid and Chowdhury (2013), recent researchers have recognized a relationship between globalization and the English Language implication in employability and high earnings in the job market. Lin and Jarvie (2019) argued that since Globalization is a genuine and relevant historical phenomenon, educators should make necessary changes in the role of the teachers, incorporating more practice in intercultural communication, especially in English Language education. This need is strongly highlighted internationally as well as locally, following the third industrial revolution, namely the communication revolution, dominated by the English Language. The world is becoming smaller by empowering the individuals with advancements of globalization, thus pressurizing the Human Resource Management function to adapt to the changing corporate needs to add greater value (Friedman, 2007). According to Pandey, Pandey \& Naidu (2017), the English Language has become 'lingua-franca' of the commercial world or the language that is adopted as a common language between speakers whose native languages are different, regardless of geographical, social, political, or religious disparities. Thus, Erling (2014) argued that English has a strong demand across society due to its apparent economic and social value. The importance of the English language as a common language among the global community has been recognized at an early stage. At the United Nations (UN) General Assembly on February 1, 1946 (UN General Assembly 
Resolutions, 1946) English Language was recognized as an official language of the UN, along with Chinese, French, Russian and Spanish, and also English as a working language with French.

\subsection{The Problem Context: Global and Local Perspective}

In September 2015, the General Assembly of the United Nations adopted the '2030 Agenda'- Transforming our world: the 2030 Agenda - for Sustainable Development of its Member States (UN General Assembly Resolutions, 2015). This is recognized as a plan of action for people, planet, and prosperity, aiming at strengthening universal peace in greater freedom. It includes 17 Sustainable Development Goals (SDGs) or 17 Global Goals. This is a holistic approach to achieving sustainable development for all nations as a universal call, to end poverty, protect the planet and ensure that all people enjoy peace and prosperity by 2030 (UN Sustainable Development Goals Report, 2020). Enhancing the English Language standards in schools appears to have a considerable impact on achieving two important SDGs out of the 17 Global Goals. Namely, Goal 4: Quality Education - 'Ensure inclusive and equitable quality education and promote lifelong learning opportunities for all' and Goal 8: 'Decent Work and Economic Growth - Promote sustained, inclusive, and sustainable economic growth, full and productive employment, and decent work for all, require quality English knowledge and skills in individuals to realize these SDGs goals by 2030. The world Bank Group is the largest sponsor of education in the developing world. The developing countries, including Sri Lanka, receive many assistances from the World Bank on educational programs and research, to reach Sustainable Development Goal 4: Quality Education and lifelong learning opportunities for all by 2030 .

However, after five years since the adoption of the SDGs Agenda for 2030 in September 2015, the progress of Sustainable Development Goal 4: Quality Education reveals alarming results, as highlighted in the current UN Sustainable Development Goals Report, 2020 (UN Sustainable Development Goals Report 2020). It revealed that despite the progress made over the past five years, the world is not on track to meet the Sustainable Development Goal No. 4: Quality Education, targeted by -the year 2030. The Report highlighted that before the COVID-19 outbreak, the projections had shown "globally, more than 200 million children would be out of school, and only 60 percent of young people would be completing upper secondary education in 2030." Education systems worldwide have been affected immediately by the Covid-19 crisis. School closures for long breaks have affected the school children and youth. Children and youth in helpless and underprivileged communities are particularly at high risk of educational exclusion. Hence, "the pandemic is deepening the education crisis and widening existing educational inequalities." (UN Sustainable Development Goals Report, 2020). The findings in the Report is emphasizing the need of improving Goal 4: Quality Education, or to ensure inclusive and equitable quality education and promote lifelong learning opportunities for all by 2030 . Hence, it is important to improve the English language standards in schools to ensure quality education and ensure school leavers and graduates will be employable, as a result of their English language competence or knowledge and skills in quality English language.

Further, the review of Sustainable Development Goal 8: Decent Work and Economic Growth - Promote sustained, inclusive, and sustainable economic growth, full and productive employment and decent work for all, too had revealed slow progress and challenge to achieve this goal by the year 2030 (UN Sustainable Development Goals Report, 2020). The global COVID-19 pandemic is projected to impact the global unemployment rate in the future. Already the 'UN Sustainable Development Goals Report, 2020' highlighted that global unemployment may reach a historic high in 2020. This will be the biggest increase in global unemployment since World War II, depending on the policies adopted by member states. It further revealed a considerably higher rate of unemployment among young workers than among adults in all global regions in 2019.

To achieve Goal 8: Decent Work and Economic Growth, it is necessary to have a competitive employment market globally as well as locally. However, according to Roshid and Chowdhury $(2013$, p. 68) researchers have argued that "a competitive market requires good communication skills in workplaces and within that, increasingly under globalization, English as communication skills plays a crucial role in employment." Thus, the English Language skills of an individual influence its prospects of employment, especially in contributing to the possibility of "secure" and "better" jobs especially for individuals from non-English speaking (Roshid and Chowdhury, 2013).

In the Sri Lankan context too, over the past five decades, the importance of improving English language standards in schools has been recognized as a desperate need by the policymakers and school authorities. This is due to the English language becoming a medium of communication, both at the international as well as at intra-national levels, increasing the chances of quality employability for school leavers and graduates. The 
Post-independent governments of Sri Lanka have given great prominence to encourage English fluency among the Sri Lankans, thus, continuing to be the acknowledged educational policy as in the present (Karunaratne, 2009). According to Udagama (1999), English is the language most Sri Lankans like to learn other than the first language. According to Sittarage (2018), improved English communication skills could lead to improved social skills and better job opportunities in Sri Lanka. Besides, it is also recognized as a status symbol in Sri Lanka, thus establishing a good command of the English language is an essential qualification for anyone who seeks to fit into the elite class in the society (Karunaratne, 2009). In Sri Lanka, English is taught as a second language as a subject within a larger syllabus, in its secondary schools.

\subsection{Justification of the Research Problem}

In the preliminary study of this research based on global and local scientific evidence in the extant literature, the researchers have identified a vital research gap in the English language standards in Sri Lankan schools. How some selected Socio-Economic factors of stakeholders: Parents, School Principals, Teachers, Students, School Management would impact on English language standards in Sri Lankan schools has not been explored in past literature in the Sri Lankan context. This vital research gap in the Sri Lankan education sector needs to be bridged on an urgent basis, considering its strong link to the English Language competence of school leavers and undergraduates, linking to the unemployment rate of the country.

Sri Lanka has a high level of literacy rate (99 \%) of youth between the age group 15-24 years (The World Bank: Literacy rate, youth total \% of people ages 15-24, in 2018). However, the highest overall youth unemployment rate $(21.5 \%)$ in Sri Lanka is also reported from this age group of 15-24 years (Sri Lanka Labour Force Survey Annual Report - 2019). The majority of unemployed youth are new entrants to the job market or new job seekers, who are in the age group $20-24$ years. Further, the youth unemployment rate was considered as a proportion of the overall unemployment rate (4.8\%) of Sri Lanka in 2019. The highest rate $(52.9 \%)$ of youth unemployment is reported from the Grade 6-10 group in the level of education. This group includes the school drop-outs before O-Level or A-Level exams.

It was also reported that the youth unemployment rate is higher among the educated group with G. C. E. (A/L) and above qualifications (30.7\%). The youth unemployment rate was at $22.5 \%$ with GCE O/L in the level of education. Hence, the new youth who are entering the labor force after completing their school education at GCE $\mathrm{O} / \mathrm{L}$ and GCE A/L show higher unemployment rates in Sri Lanka (Sri Lanka Labour Force Survey Annual Report - 2019). It has been noted over the past three decades that those who are well-ahead of others with their academic qualifications, still find it difficult to be employed. Also, English Language competence is a deciding factor to get a lucrative job, especially in the private sector, in the globalized new market economy.

Hence, why is it important to enhance English language standards in Sri Lankan schools? Competence or knowledge and skills in the second language, English, is very important for a child to have a complete education at the school level. Increasing the English learning standards in schools in Sri Lanka will contribute to students' complete education and thereby enhance their employability in the future. Reducing unemployment in developing countries will contribute to the economic growth and financial stability of the developing nations. 'Investment in human capital is key to unlocking a child's potential and improving economic growth in every country' (The World Bank, Human Capital Index Report, Sept. 2020). A child born in Sri Lanka today will be $60 \%$ as productive when he/she grows up as compared to if he/she enjoyed complete education and full health. This is higher than the average for the South Asia region and lower-middle-income countries (The World Bank, Human Capital Index Report, 2020).

\subsection{Research Problem and Research Objectives of the Study}

Based on the above scholarly arguments and research gaps identified in the extant literature, evidence from formal reports of reputed organizations and government institutions, the authors have identified the Main Research Problem of the study as follows:

Main Research Problem

"What is the Impact of Socio-Economic Factors of stakeholders on English Language Standards in Sri Lankan Schools?

The present study aims at developing a Conceptual Model to improve English Language standards in Sri Lankan Schools. Further, this Model will be used by the authors in a future study, to address the above Main Research Problem. Based on the Main Research Problem, specific research questions were developed as follows. 
Specific Research Questions:

1. What is the impact of socio-economic factors of the Education Policy Makers on English language standards in Sri Lankan Schools?

2. What is the impact of socio-economic factors of School Management on English language standards in Sri Lankan Schools?

3. What is the impact of socio-economic factors of School Principals on English language standards in Sri Lankan Schools?

4. What is the impact of socio-economic factors of English Language Teachers on English language standards in Sri Lankan Schools?

5. What is the impact of socio-economic factors of Students on English language standards in Sri Lankan Schools?

6. What is the impact of socio-economic factors of Parents on English language standards in Sri Lankan Schools?

\subsection{Research Objectives of the Study}

Main Research Objective:

The main research objective of the study is to develop a Conceptual Model to address the Main Research Problem:

To examine the impact of Socio-Economic Factors of stakeholders on English Language Standards in Sri Lankan Schools.

To achieve the Main Research Objective, six specific research objectives were developed.

Specific Research Objectives:

1. To examine the impact of socio-economic factors of the Education Policy Makers on English language standards in Sri Lankan Schools.

2. To explore the relationship between socio-economic factors of School Management and English language standards in Sri Lankan Schools.

3. To investigate the impact of socio-economic factors of School Principals on English language standards in Sri Lankan Schools.

4. To explore the relationship between socio-economic factors of English Language Teachers and English language standards in Sri Lankan Schools.

5. To identify the relationship of socio-economic factors of Students and English language standards in Sri Lankan Schools.

6. To examine the impact of socio-economic factors of Parents on English language standards in Sri Lankan Schools.

An integrated Conceptual Model, based on hypothetico-deductive approach, was developed to examine the impact of socio-economic factors of six stakeholders: Education Policy Makers, School Management, School Principals, English Language Teachers, Students, and Parents, on English Language Standards in Sri Lankan Schools. This seven-construct, integrated Model will be used by the authors in a future research, to empirically address the Main Research Problem of the study. Hence, this Model would be helpful to identify valuable insights for education policymakers and school authorities in Sri Lanka, as well as in developing countries, to improve the English language standards in schools. It would fulfill a basic need of the education sector of developing countries, to produce diversify graduates of global quality in the future, to address the graduate/youth unemployment problem in such countries.

\section{Literature Review}

\subsection{Sri Lankan Education System: Levels of Education and Administrative Structure}

The General Education system in Sri Lanka comprises of different education levels: Elementary Education Level from Grades 1 to 5, Junior Secondary Level from Grades 6 to 9, and Senior Secondary Level which ranges from Grades 10 and 11. Grade 11 is rounded off by the General Certificate of Education, Ordinary Level (GCE O-Level), which is awarded based on performance in the national GCE O-Level exams. Students who achieve a higher level in five subjects (including first national language and mathematics) can proceed to the final stage of 
Senior Secondary School, named the General Certificate of Education, Advanced Level, or GCE A-Level (Ministry of Education, Sri Lanka/moe.gov.lk).

Entry into the Secondary School Level is more competitive as the students have to sit for the General Certificate of Education, Ordinary Level (GCE O-Level) Examination at the end of Grade 11, which the Certificate is awarded based on performance in the national GCE O-Level exams. Entry into the final stage of Senior Secondary School or General Certificate of Education, Advanced level (GCE A-Level) depends on student performance at the GCE O-Level examination results. They need to achieve a higher level in five subjects (inclusive of first national language and mathematics). According to the Ministry of Examination, Sri Lanka, Department of Examination statistics, In the year 2019 overall 305,427 students sat for the GCE O-Level examination and $73.84 \%$ were qualified to proceed to the senior secondary school level, GCE A-Level, based on their O-level results. In the year 2019, out of the overall 305,162 students sat for the English Language subject, $62.36 \%$ managed to pass English at the $1^{\text {st }}$ attempt (Department of Examinations, Sri Lanka: Statistics and School Performance Indices, 2019/doenet.lk).

In Sri Lanka, the government schools are recognized under the National Administrative and Management Structure for Education. These are considered under various layers of responsibility at different levels: Divisional, Zonal, Provincial and National levels, with final accountability to the Ministry of Education and HE the President of Sri Lanka. A salient feature at the National Level of School Education Administration in Sri Lanka is the responsibilities regarding the curriculum, assessment, and textbooks are divided among three different bodies. That is, the National Institute of Education (NIE) is responsible for matters related to the school curriculum (including curriculum development), the Department of Examinations (DoE) for matters related to the public examinations (Grade 5 scholarship, GCE O-Level, and A-Level), and the Educational Publications Department (EDP) for the writing, publication, and distribution of textbooks (Ministry of Education, Sri Lanka/moe.gov.lk).

The ministries and departments of the Ministry of Education at the provincial level are responsible for "policy formulation, planning of programs, provision of resources, staffing and monitoring and evaluation" for the relevant province (National Committee for Formulating A New Education Act for General Education, 2009: 28). At the local level, schools are grouped into 100-150 schools per educational zone. Further, within a zone, there are groups of about $30-40$ schools per division. Lastly, at the bottom of the Administrative structure of the Sri Lankan Education system, each school has its own administrative or managerial structure. Thus, the standard of education in general, and students in Sri Lankan schools are exposed to many different stakeholders. Hence, it is vital to investigate the impact of socio-economic factors of the stakeholders on English language learning standards in Sri Lankan schools.

\subsection{English Language Learning in Sri Lankan Schools}

According to the definition in Oxford Learners Dictionaries, an English language learner is 'a student who is learning English as a second or foreign language'.

The English Proficiency Index by Education First (2018) had indicated that the overall English language proficiency in South Asia ranges between 'Very Low' (Afghanistan) to 'Moderate' (India), with most South Asia countries, including Sri Lanka, categorized as having 'Low' English proficiency (i.e., Pakistan, Sri Lanka, and Bangladesh).

Further, it is alarming to note the deteriorating trend of the English Proficiency Index (EPI) of Sri Lanka in the Asian region, from No. 30 (Low) in 2013 ... to No. 58 (Low) in 2018 and No. 78 (very low) in 2019, with a very low English Proficiency Index (EPI) score of 47.10 (EF English Proficiency Index 2019). Hence, it is vital and timely to improve the English language standards in schools, as a solution to the root cause of high youth unemployability of the country.

The General Education Reforms introduced over the past six decades in Sri Lanka, during post-independence, has a major role to play in the present English language standards in Sri Lankan schools. The Sri Lankan government had provided free education to all its citizens since the implementation of its Free Education Policy in October 1945. This Policy was based on the concept of the right to education and enacted tuition-free education from basic education level to the university education level in Sri Lanka. The General Education Policy of Sri Lankan schools has undergone several reforms over the decades, and for example, the Reforms introduced in 1997 and 2003 have been designed to promote equitable access to basic education and development in learning outcomes (Little, 2011). These reforms were focused on a more competency-based curriculum, for the Primary (Grades 1-5) and Junior Secondary (Grades 6-9) stages of the Sri Lankan school education system. Education researchers have identified important General Educational competencies such as 
competencies in communication, competencies relating to personality development, competencies relating to preparation for the world of work, and competencies relating to 'learning to learn' which are specifically relevant to the development of English language learning (Widanapathirana, Mampitiya, Jayawardena, \& Chandratilleke, 2016). According to Karunartne (2009), social class factors of students in particular and school learning factors in general, affect English learning in Sri Lankan schools.

Further, the medium of instructions in schools plays a critical role in the English language standards in Sri Lankan schools. In Sri Lanka, most schools use the medium of instructions as one of the two official languages, namely Sinhala (62\%) or Tamil (30\%), as indicated in the School Census Report, 2017 (Ministry of Education, Sri Lanka). According to Walisundara \& Hettiarachchi (2016), following an amendment made in 1987 to the country's 1978 constitution, English has been recognized as a 'link language' in Sri Lanka. Hence, English is used as the medium of instruction in some schools, in combination with one or both official languages: Sinhala and Tamil. In Sri Lanka, $73.2 \%$ of the students have Sinhala, $25 \%$ of students have Tamil and $1.8 \%$ of students have English as their medium of instruction in schools. The few students use English as their medium of instructions in schools are scattered mainly in three provinces in Sri Lanka: Western Province (30\%), Central Province (15\%), and the North Western Province (14\%), according to the Ministry of Education statistics (2018).

In Sri Lanka, irrespective of the medium of instruction in schools, English is introduced from the Key Stage 1, at Grade 1, as a means of communication through 'Activity Based Oral English teaching, through guided play activity, connected with the subject 'Environmental Related Activity' (Widanapathirana et al., 2016).

In Sri Lanka, English is more formally introduced as a subject only from Key Stage 2 or from Grade 3 and 4. Further, English is one of twelve subjects in the common curriculum in the junior secondary school stage (Grades 6-9). However, according to a circular issued by the Ministry of Education in the year 2008, beyond this level of school education English can be used as a medium of instruction in a specified set of subjects (Widanapathirana et al., 2016). In the Sri Lankan school education system, the English language becomes a core subject at the senior secondary level (Grades $10 \& 11$ ). Hence, the subject 'General English' is a mandatory subject in the curriculum, which requires a minimum 'pass' to be eligible to enter a University in Sri Lanka.

\subsection{English Language Standards in Schools and Socio-Economic Factors of Stakeholders}

English Language Standards in Schools:

Improving the English Language Standards in Schools has been the primary focus or interest of the authors in the proposed Model. Hence, the Dependent Variable in the Conceptual Model has been considered as the 'English Language Standards in Schools (ELS).'

In the Oxford English Learner's Dictionary, the word 'Standard' is defined as 'the level of quality', especially one that people think is acceptable (Oxford English Learners Dictionary). Further, the English language learner is 'a student who is learning English as a second or foreign language.' Accordingly, a working definition has been developed to the concept 'English Language Standard in Schools' as 'the level of quality of English language in schools.'

In Sri Lanka, under the General Education system administration and management, the 'English and Foreign Languages Branch of the Ministry of Education' is solely responsible for English language teaching, learning, and assessment in Sri Lankan schools (Ministry of Education, Sri Lanka). The main goal of this Branch is stated as "to assist all students in government schools to develop literacy and competencies concerning English \& Foreign Languages to be fully equipped to perform productivity, both locally and globally, as a fully-fledged citizen." (Ministry of Education, Sri Lanka/Foreign \& English Languages Branch). Hence, all education policy decisions about English language teaching, learning, assessment, monitoring language programs across different administrative and management levels, assisting Regional English Support Centers and arranging capacity building programs, etc, is the responsibility of this Branch, under the Ministry of Education. Thus, this study had considered the 'Students' overall performance in the English Language subject at the GCE O-Level in the school' as a key 'Dimension' of the Concept, 'English Language Standards in schools.'

Also, based on scholarly arguments in the extant literature and authors' logical belief, two more dimensions have been considered in the operationalization of the Dependent Variable: English Learning Standards in schools, namely, 'Number of students in the school' and the 'Social Class' of the schools.

Hence, the 'Dependent Variable: English Language Standards in Schools' has been operationalized under three 'Dimensions' in the proposed Model: (i) GCE O-Level Results of the school in the English Language subject (ii) Number of students in the school and (iii) Social Class of the school. The three dimensions have been further operationalized into respective 'Elements' and 'Question Items' under the instrumentation of the said Construct. 


\subsection{Socio-Economic Factors of Stakeholders}

A dictionary definition of the concept 'socio-economic' refers to the interaction between the social and economic habits of a group of people (vocabulary.com/dictionary/socioeconomic). In this definition, the word 'socio' denotes 'the study of the behaviors of people', such as the ways they interact with others, including their family members. Further, the word 'economic' in this concept means the 'economy' and it relates to the income and finances of the people. Hence, in this study, the concept of Socio-economic' means the 'social and financial' aspect of the people or stakeholders. In general, 'socio-economic' factors are defined as society-related economic factors, such as income, education, employment, social class, etc. (American Psychological Association, 2017). These factors relate to and influence one another.

Further, in the education sphere, the term 'stakeholder' generally refers to anyone interested or invested in the welfare and success of a school and its students. Namely, education policymakers, school management, school principals, teachers, parents, past pupils' associations, parent-teacher organizations, well-wishers of the school, etc. In other words, stakeholders have a personal, professional, formal, or financial interest or concern or a "stake" in the school and its students. According to extant literature; researchers have identified important stakeholder influences, such as socioeconomic factors, on English language learning in schools. Based on theory and scholarly arguments in the extant literature and secondary data from education-related research reports of reputed sources (Ministry of Education, Sri Lanka, The World Bank, The British Council), the authors have identified six vital stakeholders in the Sri Lankan school education system, to examine the influence of their 'socio-economic' factors on English language standards in Sri Lankan schools.

Main stakeholders identified in the present study: (i) Education Policy Makers, (ii) School Management, (iii) School Principals, (iv) English Language Teachers, (v) Students, and (vi) Parents.

\subsection{Development of Hypotheses of the Study}

Based on theories and research evidence in the extant literature, seven hypotheses and relevant null hypotheses were developed as follows. The six hypotheses $\left(\mathrm{H}_{1}, \mathrm{H}_{2}, \mathrm{H}_{3}, \mathrm{H}_{4}, \mathrm{H}_{5}, \mathrm{H}_{6}\right)$ display the relationships between the six constructs of Socio-economic factors of stakeholders and English Learning Standards in schools. Hypothesis H: There is a significant impact of Socio-Economic Factors of stakeholders on English Learning Standards in schools, displays the overall impact of the socio-economic factors of the six stakeholders on English Learning Standards in schools.

\subsubsection{Socio-Economic Factors of Education Policy Makers on English Learning Standards in Schools}

The Education system in Sri Lanka, not exceptional to its South Asian neighbors, is too confronted with many issues about language policies in schools, and this is a result of changes in the national language policies with the changes of the governments from time to time (Walisundara \& Hettiarachi, 2015).

According to Walisundara \& Hettiarachi (2015, p. 9) "the history of English in Sri Lanka intertwined with the politics of language status, policy, privilege, and power." During the Colonial Era in Sri Lanka, before independence in 1948, the English language enjoyed the highest status in its education system and society (Walisundara \& Hettiarachi, 2015). However, as a result of the subsequent governments responding to more popular demands to gain political advantage, restricted English language, and promoted Sinhala and Tamil languages in the language policies, impacting adversely in the education system and society in the long run. According to, (Walisundara \& Hettiarachi, 2015, p. 2) "The height of this attempt was the Sinhala only policy of 1956, which led to divisions among the majority race, Sinhalese, and other minority language users." Hence, language policies are very often politically determined, thus making language planning an incomprehensible part of it (Coperahewa, 2009). However, over time, subsequent Education and Language policy changes in Sri Lanka have focused on issues relating to the two main vernacular languages in the country, namely, Sinhala and Tamil, especially in youth unemployment, demand in the modern job market in the globalized context, development activities through intra-nations, etc. The recognition of the English language as a 'link language' by the 13th amendment in 1987 to the 1978 constitution of Sri Lanka is noteworthy in this regard. In the local context, the term 'link language' is defined as 'a language that leads to better communication and understanding between different ethnic groups.'

According to $\mathrm{Hu}$ (2005), the Chinese leadership had believed that proficiency in English is an essential component of quality education, thus a great deal of policy attention has been given to basic English language education. However, the effectiveness of implementing such policy decisions nationwide too depends on the Education Policymakers' decisions to increase the number of English language trained teachers in the country, to bridge the wide gap between the demand and supply of such teachers ( $\mathrm{Hu}, 2005)$. 
In recent empirical research in China, Dai (2015) had developed a 'Three-powered' model on 'New Characteristics of Future Basic Education in China', to further highlight the influence of leaders and policymakers in improving the English Learning Standards in schools. The three powers identified: (i) 'Policy-making Power' of the local educational administration, (ii) 'Leading Power' of the school leadership, and (iii) 'Learning Power' of the students. Further, the concept 'English Learning Power' in the 'Three-powered' Model has been derived from the notion of the 'Learning Power' of the students (Dai, 2015). The model developed by Dai (2015) highlights that the Education Policy Makers, School Principals could impact on English Learning Power of students, thereby could influence the English language Standards in schools. Further, in recent research in China (Zhang, 2020) it was found that innovations in Education Policies could improve English Language standards in schools and universities, by improving students' English proficiency levels. Successful teaching methodologies introduced by Education Policy Makers in China: Task-based Learning, Project-based Learning, Outcome-based Education, Flipped Class, Blended Teaching, etc. had enhanced the English language learning effectiveness in students (Zhang, 2020). Further, these innovations in Education policies have shifted English teaching styles in China from teacher-centeredness to learner-centeredness, text-oriented basis to communication-oriented basis, and teaching English for the general purpose of teaching English for specific purposes.

Hence, this study considered the Socio-economic factors of Education Policy Makers have a significant impact on English language standards in schools. Accordingly, the following hypothesis and relevant null hypothesis were formulated.

$\mathrm{H}_{1}$ : There is a significant impact of Socio-Economic Factors of Education Policy Makers on English Language Standards in schools.

$\mathrm{H}_{01}$ : There is no significant impact of Socio-Economic Factors of Education Policy Makers on English Language Standards in schools.

\subsubsection{Socio-Economic Factors of School Management on English Language Standards in Schools}

Researchers have identified that socioeconomic factors of the School Management have a critical role to play in teaching and learning standards of students in schools, including English Language Standards, through building and maintaining an appropriate school culture. Scholars have found that the school culture impacts many critical school functions, namely, training students through competent education standards, outstanding teacher performance, maintaining quality relationships within the school, and most importantly, determining the effectiveness of education programs in the school (Barnett \& McCormick, 2004; Balkar, 2015, as cited in Kartal, 2016).

The following hypothesis and the relevant null hypothesis were developed to examine the impact of Socio-economic factors of School Management on English Language Standards in schools.

$\mathrm{H}_{2}$ : There is a significant impact of Socio-Economic Factors of School Management on English Learning Standards in schools.

$\mathrm{H}_{02}$ : There is no significant impact of Socio-Economic Factors of School Management on English Language Standards in schools.

\subsubsection{Socio-Economic Factors of School Principals on English Language Standards in schools}

In the 'Three-powered' model developed by Dai (2015) in China, the component 'Leading Power' of the school leadership, or the 'Leading Power' derived by the school principal, has been recognized as a key factor in this Model, which impact on the future basic education in China, including 'English learning power' of the students. Hence, the authors hypothesized that the school principal has a significant "Leading Power" towards the English Language Standards in schools.

Further, the 'competency level of school principal' has been recognized as a key factor in improving the effectiveness of schools, based on its academic achievements (Heck, 1992, cited in Gaziel, 2012).

Thus, to examine the impact of Socio-economic factors of the School Principal on English Language Standards in schools, the relationship was hypnotized as follows. Accordingly, the relevant null hypothesis was developed.

$\mathrm{H}_{3}$ : There is a significant impact of Socio-Economic Factors of School Principals on English Language Standards in schools.

$\mathrm{H}_{03}$ : There is no significant impact of Socio-Economic Factors of School Principals on English Learning Standards in schools. 


\subsubsection{Socio-Economic Factors of English Language Teachers on English Language Standards in Schools}

Empirical research conducted in a South African Education system, the researchers have identified that the 'teacher proficiency' in the English language has a greater impact on the student or learner English language proficiency (Nel \& Muller, 2010). Researchers have identified that teacher quality matters for the academic achievement of students and particularly important for lower-ability students (Aaronson \& Barrow, 2007).

According to Chacon (2005), there is a positive relationship between teachers' sense of efficacy and language proficiency. Further, teachers' perceived efficacy has been found correlated with self-reported English proficiency (Chacon, 2005).Teachers' sense of efficacy has strong impacts on various aspects of teaching and learning (Lee, 2009).

Hence, to examine the relationship of Socio-economic factors of English Language Teachers and English Language Standards in schools in the Model, the following hypothesis and the relevant null hypothesis were formulated.

$\mathrm{H}_{4}$ : There is a significant impact of Socio-Economic Factors of English Language Teachers on English Language Standards in schools.

$\mathrm{H}_{04}$ : There is no significant impact of Socio-Economic Factors of English Language Teachers on English Language Standards in schools.

\subsubsection{Socio-Economic Factors of Students on English Language Standards in Schools}

In an empirical study conducted in Chile, Santiago, with secondary school students belonged to different social classes, the researchers found that the social class of the student belonged to has an overall medium-size effect on motivational factors related to the socio-economic status of English learning standard of the students (Kormos \& Kiddle, 2013). Technology has a positive impact on language learning, as it can increase the level of student engagement, thus maximizing the capacity to grasp information (Costley, 2014). This view was supported in a recent empirical study conducted involving Jordanian University students, by discovering that the internet is important in learning English language skills, developing their self-learning skills, self-confidence, and influencing their learning attitude and strengthening their linguistic skills in the English language (Tartory, 2020).

The following hypothesis and the relevant null hypothesis were developed to examine the impact of Socio-economic factors of students on English Language standards in schools.

$\mathrm{H}_{5}$ : There is a significant impact of Socio-Economic Factors of Students on English Learning Standards in schools.

$\mathrm{H}_{05}$ : There is no significant impact of Socio-Economic Factors of students on English Learning Standards in schools.

\subsubsection{Socio-Economic Factors of Parents on English Language Standards in Schools}

Researchers have identified that socio-economic factors of parents have an important role to play in the English language learning of students (Kormos \& Kiddle, 2013; Nikolov, 2009). According to Kormos \& Kiddle (2013), the Report (2003) of Program for International Student Assessment in Chile, Santiago, the students whose parents had higher education qualifications had performed better in the language proficiency test than vice versa. In Hungary, Nikolov (2009) too observed a similar trend, which showed a strong link between the students' achievement in language learning proficiency and the parents' level of education qualifications.

The following hypothesis and the relevant null hypothesis were developed to examine the impact of Socio-economic factors of Parents on English Language standards in schools.

$\mathrm{H}_{6}$ : There is a significant impact of Socio-Economic Factors of Parents on English Learning Standards in schools.

$\mathrm{H}_{06}$ : There is no significant impact of Socio-Economic Factors of Parents on English Learning Standards in schools.

Based on the above six overall individual relationships in the Conceptual Model regarding the six identified stakeholders: Education Policy Makers, School Management, School Principal, English Language Teachers, Students, and Parents, the authors have developed the following main hypothesis $(\mathrm{H})$ to examine the joint impact of the socio-economic factors of the above six stakeholders as a bundle, on the English language standard of schools. The relevant null hypothesis $\left(\mathrm{H}_{0}\right)$ is also stated. 
H: There is a significant impact of Socio-Economic Factors of stakeholders on English Learning Standards in schools.

$\mathrm{H}_{0}$ : There is no impact of Socio-Economic Factors of stakeholders on English Learning Standards in schools.

A seven-construct Conceptual Model (Figure 1) was developed to examine the relationships and effects between the variables.

\subsection{The Conceptual Model (ELS Model)}

The Main Research Problem identified in this study is "What is the Impact of Socio-Economic Factors of stakeholders on improving English Language Standards in Sri Lankan Schools?

Guided by established theories and scholarly arguments in extant literature, based on 'hypothetico-deductive' approach, the authors have considered the 'socio-economic factors of stakeholders' as the Independent Variable of this study impacting on the Dependent Variable, 'English language standards of schools' in the proposed Conceptual Model.

Using general theories, authors' logical beliefs, research gaps, and findings in the extant literature, this paper aimed at developing a network of associations among the seven constructs of interest in this research topic. Considering the six stakeholders identified, the following seven-construct Conceptual Model (ELS Model) was proposed to improve the English language standards in schools of developing countries.

The Independent Variable: socio-economic factors of the six stakeholders identified, works as a dynamic force of the Dependent Variable: English language standards in schools. These six factors are subject to change depending on their 'socio-economic' conditions, making changes in the Dependent Variable at various degrees.

Hence, this model is proposed to examine these interactions in a nomological network, as presented in Figure 1.

\section{Independent Variable}

Socio-Economic Factors of Stakeholders

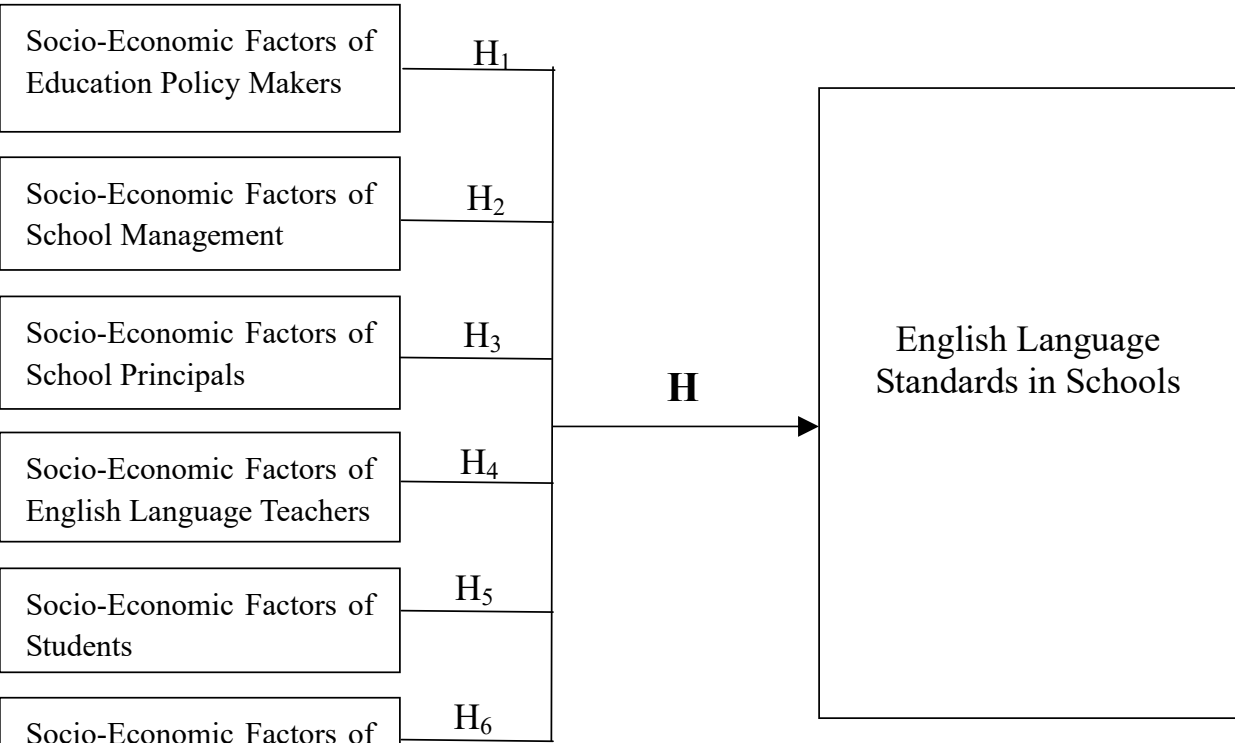

\section{Dependent Variable}

English Language Standards in Schools

Parents

Figure 1. ELS Model for Improving English Language Standards in Schools

Summary of hypotheses of the study:

This study developed a seven-construct, integrated Conceptual Model (ELS Model) for improving the English Language Standards in Schools (Figure 1). Seven hypotheses were developed on a hypothetico-deductive approach, to depict the relationships and effects between the variables in the model, as follows:

$\mathrm{H}$ : There is a significant impact of Socio-Economic Factors of stakeholders on English Learning Standards in schools.

$\mathrm{H}_{1}$ : There is a significant impact of Socio-Economic Factors of Education Policy Makers on English Language Standards in schools. 
$\mathrm{H}_{2}$ : There is a significant impact of Socio-Economic Factors of School Management on English Learning Standards in schools.

$\mathrm{H}_{3}$ : There is a significant impact of Socio-Economic Factors of School Principals on English Language Standards in schools.

$\mathrm{H}_{4}$ : There is a significant impact of Socio-Economic Factors of English Language Teachers on English Language Standards in schools.

$\mathrm{H}_{5}$ : There is a significant impact of Socio-Economic Factors of Students on English Learning Standards in schools.

$\mathrm{H}_{6}$ : There is a significant impact of Socio-Economic Factors of Parents on English Learning Standards in schools.

2.6.1 Theoretical Base of the English Language Standard (ELS) Model

The General Systems Theory (GST) Perspective

In addition to the specific empirical and theoretical evidence discussed in developing the proposed ELS Model (Figure 1) and hypotheses of this study, the overall relationships and effects in the Model are strengthened by the 'General Systems Theory' (von Bertalanffy, 1950, cited in Jackson and Schuler, 1995). According to Jackson and Schuler (1995, p. 239):

"In general systems theory, the unit of analysis is understood as a complex of interdependent parts (Bertalanffy, 1950). An open (vs closed) system is dependent on the environment for inputs, which are transformed throughput to produce outputs that are exchanged in the environment."

Open System models usually do not consider organizations or large units within organizations. However, Katz and Kahn (1978), cited in Jackson and Schuler (1995), in their work in 'The Social Psychology of Organizations' considered HRM as a subsystem embedded in a larger organizational system. Since then, this theory has become a popular, strong theory among researchers to theorize their works. Based on this perspective, the authors have considered English language education in schools as a subsystem embedded in the larger open Education system. According to the GST, the 'inputs' from the environment will go through the 'process' in the subsystem (open), to produce 'output' back to the environment, as depicted in Figure 2.

\section{Subsystem}

English Language Education

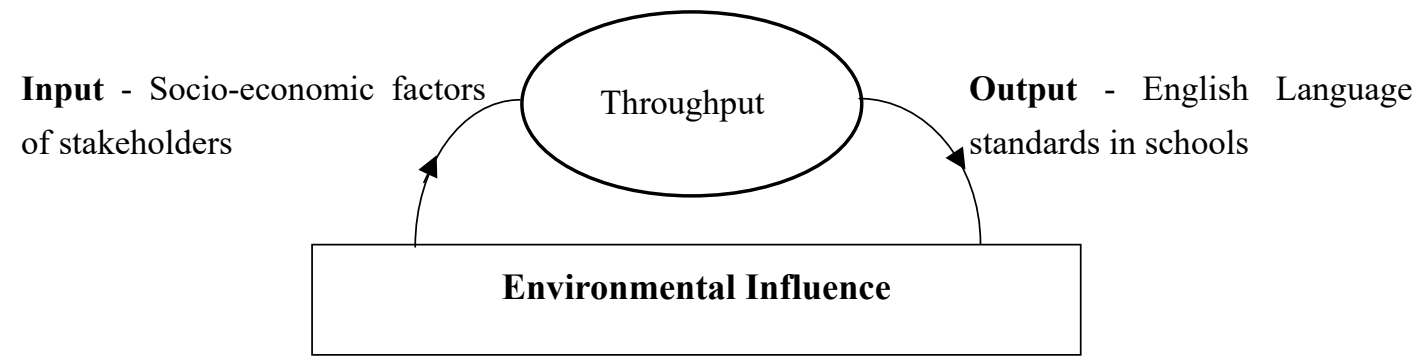

Figure 2. ELS Model - General System Theory (GST) Perspective

Applying the GST to the Conceptual Model (Figure 1), the inputs from the environment: 'socio-economic factors of stakeholders will go through the 'process' in the subsystem, English language education in schools, and produce the output to the environment, English Language standard in Schools. Hence, the GST is considered as the main theory to strengthening the overall theoretical relationships among variables in the Conceptual Model.

\section{Method}

The archival method, recommended by Tranfield, Denyer, and Smart (2003) was used in this study to develop a wide-ranging understanding of the research topic, to identify the main concepts in the proposed Conceptual Model, their relationships and effects with other key concepts considered in the Model. The Model development was based on existent theories from scholarly theoretical and empirical research articles, established general theories, secondary data from reliable government sources in Sri Lanka, and reputed international organizations, 
namely the World Bank, USA, and British Council, UK. The literature review was based on a general search of scholarly articles, published over the past three decades, in peer-reviewed journals in on-line databases such as the Canadian Center of Science and Education, JSTOR, SAGE journals, ScienceDirect, SpringerLink, Taylor \& Francis Online, Wiley Online, etc., using search terms and phrases such as English language education, foreign/second language education in developing countries, English language learning standards, socio-economic factors on school education, socio-economic factors and English language, etc. After reading through the abstracts of about 100 articles published in reputed peer-reviewed journals through online databases, authors selected about 40 articles, directly relevant to the topic, with a reasonable number of citations, to be studied in detail. Besides, reports published on websites of reputed institutions and government departments were also studied in detail.

\section{Discussion, Conclusion, and Recommendations}

\subsection{Discussion and Conclusion}

The purpose of the study was to develop a Conceptual Model to examine the impact of Socio-Economic Factors of stakeholders on English Language Standards in Sri Lankan Schools. To address the Main Research Problem: "What is the Impact of Socio-Economic Factors of stakeholders on English Language Standards in Sri Lankan Schools?

The study developed an integrated seven-construct, Conceptual Model, labeled 'English Language Standard (ELS) Model', to improve the English Language Standards in Sri Lankan schools.

The study identified six main stakeholders: (i) Education Policy Makers, (ii) School Management, (iii) School Principal, (iv) English Language Teachers, (v) Students and (vi) Parents, who could influence the English Language Standards in Sri Lankan Schools though their socioeconomic factors.

The study recognized seven key Variables and respective Dimensions in the English Language Standard (ELS) Model:

Dependent Variable- English Language Standards in Schools.

The Dependent Variable: English Language Standards in Schools was operationalized under three 'Dimensions': (i) GCE O-Level Results of the English Language (ii) Number of students and (iii) Social class of the school.

Main Independent Variable- Socio-Economic factors of the Stakeholders (Education Policy Makers, School Management, School Principal, English Language Teachers, Students, and Parents).

The Main Independent Variable was operationalized under six Dimensions: (i) Socio-economic factors of Education Policymakers, (ii) Socio-economic factors of School Management, (iii) Socio-economic factors of School Principal, (iv) Socio-economic factors of English Language Teachers, (v) Socio-economic factors of Students and (vi) Socio-economic factors of Parents.

Further, the authors formulated seven hypotheses $(\mathrm{H}, \mathrm{H} 1, \mathrm{H} 2, \mathrm{H} 3, \mathrm{H} 4, \mathrm{H} 5, \mathrm{H} 6)$ on the hypothetic-deductive approach, based on extant literature and general theories. These hypotheses and their relevant null-hypotheses were formulated to address seven specific research problems, to address the Main Research Problem of the study. The theoretical base of the overall 'ELS Model' or the relationships and effects in the Conceptual Model was strengthened by the 'General Systems Theory' (von Bertalanffy, 1950, cited in Jackson and Schuler, 1995).

The findings of the study theoretically identified that the Socio-Economic factors of the Stakeholders (Education Policy Makers, School Management, School Principal, English Language Teachers, Students and Parents) impact on the English Language Standards in Sri Lankan Schools.

\subsection{Recommendations}

The theoretical 'ELS Model' developed has been validated through a Pilot Study, conducted in the Sri Lankan secondary school study setting in the Western Province, Sri Lanka. The ELS Model could be used by other developing countries too, to improve the English Language standards in schools to address similar problems. This study had created new knowledge in the existing knowledge domain of English language teaching and learning as a second language or foreign language, to improve the English Language Standards in schools in developing countries, including Sri Lanka. Further, researchers could use the ELS Model presented in this paper as a theoretical basis for the development of country-specific ELS Models and appropriate measurement instruments in further research studies. 


\section{Acknowledgment}

This research was supported by the Accelerating Higher Education Expansion and Development (AHEAD) Operation of the Ministry of Higher Education, Sri Lanka, funded by the World Bank.

\section{References}

Aaronson, D., Barrow, L., \& Sander, W. (2007). Teachers and student achievement in the Chicago public high schools. Journal of Labor Economics, 25(1), 95-135. https://doi.org/10.1086/508733

American Psychological Association. Education and Socioeconomic Status. (2017). Retrieved from https://www.apa.org/pi/ses/resources/publications/education

Chacón, C. T. (2005). Teachers' perceived efficacy among English as a foreign language teachers in middle schools in Venezuela. Teaching and Teacher Education, 21(3), 257-272. https://doi.org/10.1016/j.tate.2005.01.001

Coperahewa, S. (2009). The language planning situation in Sri Lanka. Current Issues in Language Planning, 10(1), 69-150. https://doi.org/10.1080/14664200902894660

Costley, K. C. (2014). The Positive Effects of Technology on Teaching and Student Learning. Online Submission.

Dai, Z. (2015). The Concept of "English Learning Power" and Its Implication for the Design of English Curricula for Primary and Middle Schools in China. Journal of Education and Practice, 6(36), 128-133.

Department of Examinations, Sri Lanka: Statistics and School Performance Indices. (2019). Retrieved from https://www.doenets.lk/statistics

English Proficiency Index by Education First. (2018). Retrieved from https://www.ef.com/wwen/epi/regions/asia/sri-lanka/

Erling, E. (2014). Role of English in skills development in South Asia.

Friedman, M. (2007). The social responsibility of business is to increase its profits. Corporate ethics and corporate governance (pp. 173-178). Springer, Berlin, Heidelberg. https://doi.org/10.1007/978-3-540-70818-6_14

Gaziel, H. H. (1997). Impact of school culture on the effectiveness of secondary schools with disadvantaged students. The Journal of Educational Research, 90(5), 310-318. https://doi.org/10.1080/00220671.1997.10544587

Hu, G. (2005). English Language Education in China: Policies, Progress, and Problems. Lang Policy, 4, 5-24. https://doi.org/10.1007/s10993-004-6561-7

Jackson, S. E., \& Schuler, R. S. (1995). Understanding human resource management in the context of organizations and their environments. Annual review of psychology, 46(1), 237-264. https://doi.org/10.1146/annurev.ps.46.020195.001321

Kartal, S. E. (2016). Determining school administrators' perceptions of institutional culture: A qualitative study. Educational Process: International Journal (EDUPIJ), 5(2), $152-166$. https://doi.org/10.12973/edupij.2016.52.6

Karunaratne, I. M. (2009). Teaching of English: A sociological study. APH Publishing.

Kormos, J., \& Kiddle, T. (2013). The role of socio-economic factors in motivation to learn English as a foreign language: The case of Chile. System, 41(2), 399-412. https://doi.org/10.1016/j.system.2013.03.006

Lee, J. A. (2009). Teachers' sense of efficacy in teaching English, perceived English language proficiency, and attitudes toward the English language: A case of Korean public elementary school teachers (Doctoral dissertation, The Ohio State University).

Lin, G. H. C., \& Jarvie, D. S. (2019). Globalisation Education. Online Submission.

Literacy rate, youth total (\% of people ages 15-24). (2018). Retrieved from https://data.worldbank.org/indicator/SE.ADT.1524.LT.ZS

Little, R. (2011). Britain's response to the Spanish Civil War: investigating the implications of foregrounding practice for English school thinking. CAMBRIDGE STUDIES IN INTERNATIONAL RELATIONS, 119(1), 174-199. https://doi.org/10.1017/CBO9780511862373.011

Ministry of Education, Sri Lanka. Retrieved from https://www.moe.gov.lk/ 
National Committee for Formulating. (2009). A New Education Act for General Education, 2009:28. Retrieved from http://nec.gov.lk/wp-content/uploads/2017/12/Towards-a-New-Education-Act.pdf

Nel, N., \& Müller, H. (2010). The impact of teachers' limited English proficiency on English second language learners in South African schools. South African Journal of Education, 30(4). https://doi.org/10.15700/saje.v30n4a393

Nikolov, M. (2009). The dream and the reality of early programs in Hungary. Young learner English language policy and implementation: International perspectives, 121-130.

Oxford Learners Dictionaries. Retrieved from https://www.oxfordlearnersdictionaries.com/definition/

Pandey, M., Pandey, P., \& jini Naidu, S. (2017). Better English for better employment opportunities. PAKISTAN JOURNAL OF LANGUAGE AND LINGUISTICS, 1(1), 1-5.

Roshid, M. M., \& Chowdhury, R. (2013). English language proficiency and employment: A case study of Bangladeshi graduates in the Australian employment market. Online Submission, 3(1), 68-81. https://doi.org/10.13054/mije.13.06.3.1

School Census of Sri Lanka. (2018). Retrieved from https://www.guruwaraya.lk/2020/05/school-census-of-Sri-Lanka-2018.html

Sittarage, N. P. K. (2018). English Language Education in Sri Lanka Link with the Learners' Motivational Factors. Humanising Language Teaching, 20(4).

Socioeconomic Dictionary. Retrieved from https://www.vocabulary.com/dictionary/socioeconomic

Sri Lanka Labour Force Survey Annual Report. (2019). Retrieved from http://www.statistics.gov.lk/Resource/en/LabourForce/Annual_Reports/LFS2019.pdf

Tartory, R. (2020). Jordanian Students' Perceptions, Understanding, and Knowledge towards the Role of Internet in Learning "Englishes" and English Language Skills. English Language Teaching, 13(10), 38-56. https://doi.org/10.5539/elt.v13n10p38

The World Bank. (2020). Human Capital Index Report, Sept. 2020. Retrieved from https://openknowledge.worldbank.org/handle/10986/34432

Tranfield, D., Denyer, D., \& Smart, P. (2003). Towards a methodology for developing evidence-informed management knowledge by means of systematic review. British journal of management, 74(3), 207-222. https://doi.org/10.1111/1467-8551.00375

Udagama, P. (1999). Rhetoric and reality: Education in Sri Lanka after independence. Amal Publishing Company.

UN General Assembly Resolutions. (1946). Retrieved from http://www.worldlii.org/int/other/UNGA/1946/

UN General Assembly Resolutions. (2015). Transforming our world: the 2030 Agenda for Sustainable Development. Retrieved from https://www.un.org/en/development/desa/population/migration/generalassembly/docs/globalcompact/A_RE S_70_1_E.pdf

UN Sustainable Development Goals Report. (2020). Retrieved from https://www.un.org/sustainabledevelopment/progress-report/

Walisundara, D. C., \& Hettiarachchi, S. (2016). English language policy and planning in Sri Lanka: A critical overview. In English Language Education Policy in Asia (pp. 301-332). Springer, Cham. https://doi.org/10.1007/978-3-319-22464-0_14

Widanapathirana, S., Mampitiya, U., Jayawardena, R. C., \& Chandratilleke, K. L. (2016). Study on Curriculum Development in General Education in Sri Lanka.

Zhang, H. (2020). Application of a production-oriented Approach in College English Instruction in China: A Case Study. English Language Teaching, 13(10), 14-22. https://doi.org/10.5539/elt.v13n10p14

\section{Copyrights}

Copyright for this article is retained by the author(s), with first publication rights granted to the journal.

This is an open-access article distributed under the terms and conditions of the Creative Commons Attribution license (http://creativecommons.org/licenses/by/4.0/). 